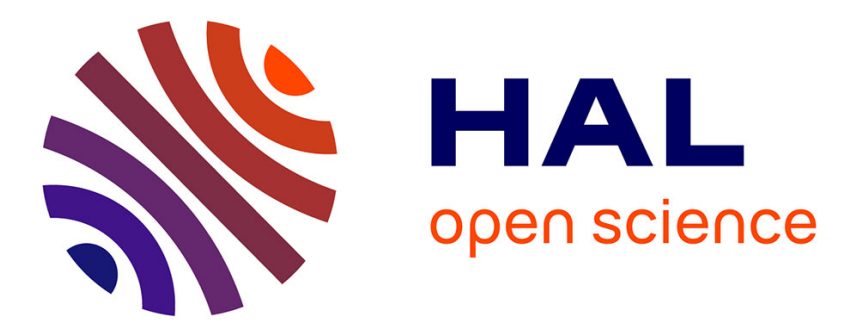

\title{
The rbc L gene sequence from chestnut indicates a slow rate of evolution in the Fagaceae
}

\author{
Nathalie Frascaria, Laurent Maggia, Martin Michaud, Jean Bousquet
}

\section{To cite this version:}

Nathalie Frascaria, Laurent Maggia, Martin Michaud, Jean Bousquet. The rbc L gene sequence from chestnut indicates a slow rate of evolution in the Fagaceae. Genome, 1993, 36 (4), pp.668-671. 10.1139/g93-089 . hal-03494294

\section{HAL Id: hal-03494294 \\ https://hal.science/hal-03494294}

Submitted on 5 Jan 2022

HAL is a multi-disciplinary open access archive for the deposit and dissemination of scientific research documents, whether they are published or not. The documents may come from teaching and research institutions in France or abroad, or from public or private research centers.
L'archive ouverte pluridisciplinaire HAL, est destinée au dépôt et à la diffusion de documents scientifiques de niveau recherche, publiés ou non, émanant des établissements d'enseignement et de recherche français ou étrangers, des laboratoires publics ou privés. 


\title{
The $r b c \mathrm{~L}$ gene sequence from chestnut indicates a slow rate of evolution in the Fagaceae ${ }^{1}$
}

\author{
Nathalie Frascaria, Laurent Maggia, Martin Michaud, and Jean Bousquet ${ }^{2}$ \\ Centre de recherche en biologie forestière, Département des sciences forestières, \\ Faculté de foresterie et de géomatique, Université Laval, Ste-Foy, QC GIK 7P4, Canada \\ Corresponding Editor: G. Bellemare \\ Received November 10, 1992 \\ Accepted April 1, 1993
}

\begin{abstract}
Frascaria, N., Maggia, L., Michaud, M., and Bousquet, J. 1993. The $r b c$ L gene sequence from chestnut indicates a slow rate of evolution in the Fagaceae. Genome, 36: 668-671.

The nucleotide sequence was obtained for the chloroplast gene coding for the large subunit of the ribulose 1,5-bisphosphate carboxylase $(r b c \mathrm{~L})$ of chestnut (Castanea sativa Mill.), a member of the woody family Fagaceae. Amplification primers downstream and upstream the $r b c \mathrm{~L}$ open reading frame are also described. By comparing with other angiosperm sequences, we show that the rate of evolution of $r b c \mathrm{~L}$ in the family Fagaceae is much slower than that observed for the families of annuals analyzed.

Key words: angiosperms, Castanea sativa, Fagaceae, phylogeny, $r b c \mathrm{~L}$.
\end{abstract}

Frascaria, N., Maggia, L., Michaud, M., et Bousquet, J. 1993. The $r b c$ L gene sequence from chestnut indicates a slow rate of evolution in the Fagaceae. Genome, $36: 668-671$.

La séquence nucléotidique du gène chloroplastique codant pour la grosse sous-unité de l'enzyme ribulose 1,5-diphosphate carboxylase $(r b c \mathrm{~L})$ a été déterminée pour le châtaignier (Castanea sativa Mill.), un membre de la famille ligneuse des Fagaceae. Des amorces d'amplification en amont et en aval du cadre de lecture de $r b c \mathrm{~L}$ sont aussi décrites. La comparaison avec d'autres séquences d'angiospermes a permis de démontrer que le taux d'évolution du gène $r b c \mathrm{~L}$ dans la famille des Fagaceae est beaucoup plus lent que celui observé chez les familles d'annuelles analysées.

Mots clés : angiospermes, Castanea sativa, Fagaceae, phylogénie, $r b c \mathrm{~L}$.

DNA sequence comparisons of chloroplast-encoded genes is now routinely used to investigate phylogenetic relationships among angiosperms and other plants (Wolfe et al. 1989). In recent years, there has been a growing interest in using sequences of the gene coding for the large subunit of ribulose 1,5-bisphosphate carboxylase/ oxygenase $(r b c \mathrm{~L})$ to estimate plant phylogenies (Ritland and Clegg 1987). The substitution rate of $r b c \mathrm{~L}$ appears appropriate for studies involving taxa that diverged from 10 's of million to 100's of million years (Zurawski et al. 1984). In this paper, we report the complete nucleotide sequence of the $r b c \mathrm{~L}$ open reading frame (ORF) for a woody angiosperm, the chestnut of the family Fagaceae, Castanea sativa Mill. We show that the rate of evolution of $r b c \mathrm{~L}$ in this family is much slower than that observed for families of annual angiosperms. Implications for phylogenetic studies using $r b c \mathrm{~L}$ are briefly discussed.

$r b c \mathrm{~L}$ was amplified symmetrically following previously published procedures (Bousquet et al. 1992a). Seven primers, internal to the ORF, were used for amplification and sequencing and were designed from the alignment of previously published ORF sequences of dicots (Bousquet et al. 1992 $b$ ): for sequencing the $5^{\prime}-3^{\prime}$ strand, $334^{+}: 5^{\prime}$ TC TGT TAC TAA CAT GTT TAC TTC-3'; 691 ${ }^{+}: 5^{\prime}-\mathrm{GA}$ AAC AGG TGA AAT CAA AGG GCA TTA-3'; $1144^{+}$: 5'-GG TAT TCA CGT TTG GCA TAT GCC TGC-3'; and for sequencing the opposite strand, 216 : $5^{\prime}$-TC GGT CCA CAC AGT TGT CCA TGT-3'; 537 ${ }^{-}$: 5'-CC CAA

${ }^{1}$ The nucleotide sequence reported appears in the GenBank and EMBL under the accession number M94936.

${ }^{2}$ Author to whom correspondence should be addressed.
TTT AGG TTT AAT AGT ACA TCC-3'; $979^{-}: 5^{\prime}$-AAT ATG ATC TCC ACC AGA CAA ACG TAA-3'; $1303^{-}$: 5'-TCC CTC ATT ACG AGC TTG TAC ACA-3'. Primers upstream and downstream the coding region were designed from comparing Hamamelideae sequences (Bousquet et al. $1992 a$ ): upstream the primer $-34^{+}$was complementary to the $3^{\prime}-5^{\prime}$ strand, starting at the position -34: 5'-AAG TTC TTA ATT CAT GAG TCG TAG-3'; downstream the primer $1517^{-}$was complementary to the $5^{\prime}-3^{\prime}$ strand, starting at the position 1517: 5' -TTA GTA AAA GAT TGG GCC GAG TTT-3'. Direct sequencing of the two DNA strands was performed with the dideoxynucleotide chaintermination procedure using the Sequenase version $2.0 \mathrm{kit}$ with dITP nucleotide mixes (USB) as recommended by the manufacturer, except that times and temperatures were modified (Zimmerman and Fuscoe 1991).

The coding region of the chestnut $r b c \mathrm{~L}$ was $1428 \mathrm{bp}$ long. The chestnut sequence was very similar to red oak (Quercus rubra) (Bousquet et al. 1992a) (Fig. 1), another member of the family Fagaceae, with only 12 nucleotide differences for a DNA homology of $99.1 \%$. Otherwise, the chestnut sequence was $90.1 \%$ identical to tobacco (Nicotiana tabacum) (Shinozaki and Sugiura 1982), $86.5 \%$ to maize (Zea mays) (Gaut et al. 1992), and $83.5 \%$ to Douglas-fir (Pseudotsuga menziesii) (Hipkins et al. 1990).

Synonymous and nonsynonymous rates of evolution and their standard errors in different annual and woody families of dicots and monocots were calculated ( $\mathrm{Li}$ et al. 1985). Overall rates of substitution were estimated using a weighted average of $K_{\mathrm{s}}$ and $K_{\mathrm{a}}$, the two-parameter method of Kimura (1980), and the one-parameter method 
CS 1 ATG TCA CCA CAA ACA GAG ACT AAA GCA AGT GTT GGA TTC AAA GCT GGT GTT

Qr 1 . $\ldots \ldots \ldots \ldots \ldots$

AAA GAT TAT AAA TTG ACT TAT tAT ACT CCT GAC TAT CAA ACC AAA GAT ACT 102

52 AAA GAT TAT AAA TTG ACT TAT

103 GAT ATC TTG GCA GCC TTC CGA GTA ACT CCT CAA CCT GGA GTT CCG CCg GAG

102

GAA GCA GGG GCC GCG GTA GCT GCT GAA TCT TCC ACT GGG ACA TGG AgA ACT

204

GTG TGG ACT GAC GGG CTT ACC AGT CTT GAT CGT TAC AAA GGA CGA TGC TAC

204

205

CAC ATC GAG CCg GTT GCT GGA GAA GAA AAT CAA TTT ATT GCT TAT GTA GCT

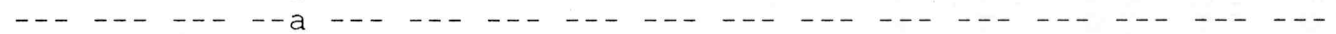

TAC CCC TTA GAC CTC TTT GAA GAA GGT TCT GTT ACT AAC ATG TTT ACT TCC

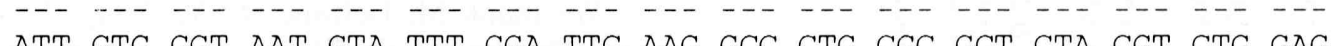

358

358

409

409

460

460

511

511

562

562

613

613

664

664

715

715

766

766

817

817
868

868
868

919

919

970

970

1021

1021

1072

1072

1123

1123

1174

1174

1225

1225

1276

1276

1327

1327

1378

1378

ATT GTG GGT AAT GIA TTT GGA TTC AAG GCC CTG CGC GCT CTA CGT CTG GAG GAT TTG CGA ATC CCT ACT TCT TAT TCT AAA ACT TTC CAA GGT CCG CCT CAT

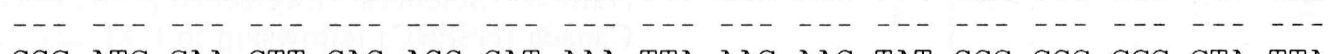
GGC ATC CAA GTT GAg AgG GAT AAA TTA AAC AAG TAT GGC CGC CCC CTA TTA GGA TGT ACT ATT AAA CCT AAA TTG GGA TTA TCC GCT AAG AAT TAC GGT AGA

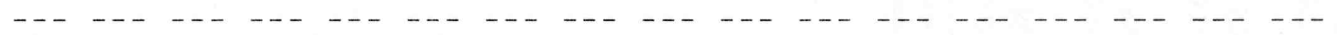
GCA GTT TAT GAA TGT CTC CGC GGT GGG CTT GAT TTT ACC AAA GAT GAT GAG

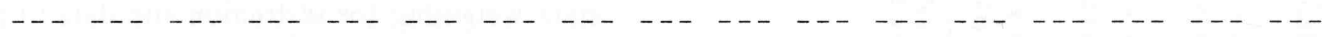
AAC GTT AAT TCC CAA CCA TTT ATG CGT TGG AGA GAC CGT TTC CTA TTT TGT

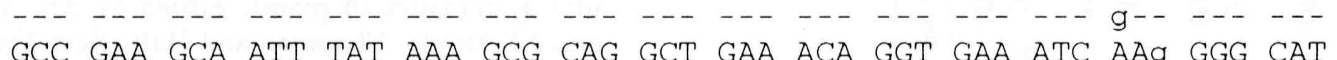

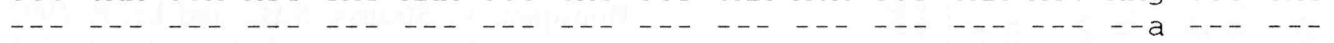
TAC TTG AAT GCT ACT GCA GGT ACA TGC GAA GAA ATG ATC AAA AGG GCT GTA -----
$\mathrm{TTT}$ II GCC AGA GAA CTG GGA GTT CCT ATC GTA ATG CAT GAC TAC TTA ACC GGG GGG TTC ACT GCA AAT ACT AGC TTG GCT CAT TAT TGC CGA GAT AAT GGT CTA

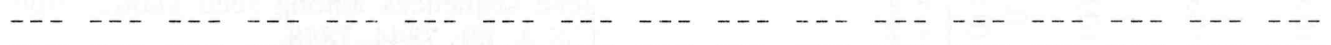
CTT CTT CAC ATC CAT CGT GCa ATG CAT GCA GTT ATT GAT CGA CAG AAG AAT CAT GGT ATA CAC TTT CGT GTA CTA GCT AAA GCA TTA CGT ATG TCT GGT GGA GAT CAT ATT CAT GCC GGT ACC GTA GTA GGT AAA CTT GAA GGG GAA AGA GAA

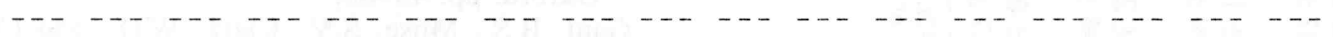
ATC ACT TTA GGC TTT GTT GAT TTA CTA CGT GAT GAT TAT ATT GAA AAA GAT CGA AGC CGC GGT ATT TAT TTC ACT CAA GAT TGG GTC TCT TTA CCA GGT GTT CGA AGC CGC GGT ATT TAT TTC ACT CAA GAT TGG GTC TCT TTA CCA GGT GTT CTG CCC GTG GCT TCA GGG GGT ATT CAC GTT TGG CAT ATG CCT GCT TTG ACC

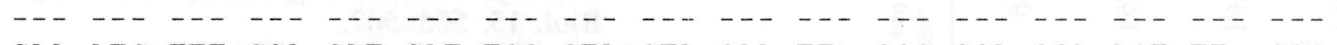
GAA ATC TTT GGA GAT GAT TCC GTA CTA CAA TTt GGC GGA GGA ACT TTg GGG

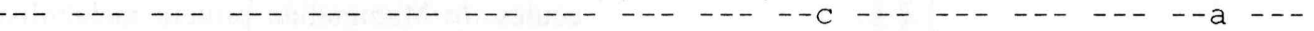
CAC CCT TGG GGA AAT GCA CCt GGT GCC GTA GCT AAT CGA GTA GCT CTA GAA

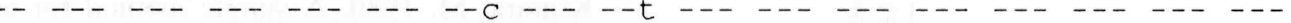
GCA TGT GTA CAA GCT CGT AAT GAG GGA CGT GAT CTT GCT CGT GAG GGT AAT GAA ATT ATt CGT GAG GCT GCT AAA TGG AGT CCT GAG CTA GCT GCT GCT TGT

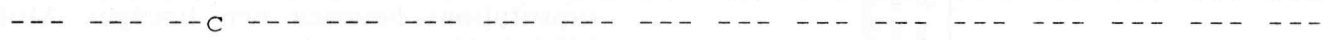

Fig. 1. Open reading frame sequence (1428 bp) of the $r b c \mathrm{~L}$ gene from Castanea sativa Mill. Differences are indicated by lowercase letters between $C$. sativa (Cs) and Quercus rubra (Qr) (Bousquet et al. 1992a), another member of the family Fagaceae.

of Jukes and Cantor (1969). For each family analyzed, a rate per year was obtained by dividing the pairwise rate between two taxa by $2 T$, where $T$ was the divergence time derived from the fossil record.

Substitution rates per year varied in a range of near one order of magnitude between the two woody and the two annual angiosperm families compared (Table 1). This difference was apparent at both synonymous and nonsynonymous sites (Table 1). The slower rate of evolution observed in the two woody families analyzed confirms a rate heterogeneity trend recently reported among seed plants for $r b c \mathrm{~L}$, although no rates per year were esti- 
mated (Bousquet et al. 1992b). This diversity of rates implies that careful analysis of rate heterogeneity among the sequences analyzed must be conducted before using this gene as a molecular clock, which assumes constancy of evolutionary rate over time (Zuckerkandl and Pauling 1965). Procedures for this purpose have recently become available (Wu and $\mathrm{Li} 1985 ; \mathrm{Li}$ and Bousquet 1992). Methods of phylogenetic tree construction, which are sensitive to rate heterogeneity (see Sourdis and Nei 1988), must also be used cautiously with this gene.

\section{Acknowledgements}

We thank M. Lefranc (ESV, Orsay, France) for providing plant materials. This work was supported by AUPELFUREF association fellowships to N.F. and L.M., by the Natural Sciences Engineering Research Council of Canada (NSERC) fellowship to L.M. and NSERC operating grant (OGP0046273) to J.B., and by Québec FCAR grants (ER-0693 and NC-0642) to J.B.

Albert, V.A., Mishler, B.D., and Chase, M.W. 1992. Characterstate weighting for restriction site data in phylogenic reconstruction with an example from chloroplast DNA. In Molecular systematics of plants. Edited by P.S. Soltis, D.E. Soltis, and J.J. Doyle. Chapman and Hall, New York. pp. 369-401.

Bousquet, J., Strauss, S.H., and Li, P. 1992a. Complete congruence between morphological and $r b c \mathrm{~L}-$ based molecular phylogenies in birches and related species (Betulaceae). Mol. Biol. Evol. 9: 1076-1088.

Bousquet, J., Strauss, S.H., Doerksen, A.H., and Price, R.A. $1992 b$. Extensive variation in evolutionary rate of $r b c \mathrm{~L}$ gene sequences among seed plants. Proc. Natl. Acad. Sci. U.S.A. 89: 7844-7848.

Crepet, W.L. 1989. History and implications of the early North American fossil record of Fagaceae. In Evolution, systematics, and fossil history of the Hamamelideae. Edited by P.R. Crane and S. Blackmore. Clarendon Press, Oxford. pp. 45-66.

Gaut, B.S., Muse, S.V., Clark, W.D., and Clegg, M.T. 1992. Relative rates of nucleotide substitution at the $r b c \mathrm{~L}$ locus of monocotyledonous plants. J. Mol. Evol. 35: 292-303.

Hipkins, V.D., Tsai, C.H., and Strauss, S.H. 1990. Sequence of the gene for the large subunit of ribulose 1,5-bisphosphate carboxylase from a gymnosperm, Douglas fir. Plant Mol. Biol. 15: 505-507.

Jukes, T.H., and Cantor, C.R. 1969. Evolution of protein molecules. In Mammalian protein metabolism. Edited by H.N. Munro. Academic Press, New York. pp. 21-132.

Kimura, M. 1980. A simple method for estimating evolutionary rates of base substitutions through comparative studies of nucleotide sequences. J. Mol. Evol. 16: 111-120.

Li, P., and Bousquet, J. 1992. Relative rate test for nucleotide substitutions between two lineages. Mol. Biol. Evol. 9: 1185-1189.

Li, W.-H., Wu, C.-I., and Kuo, C.-C. 1985. A new method for estimating synonymous and nonsynonymous rates of nucleotide substitution considering the relative likelihood of nucleotide and codon changes. Mol. Biol. Evol. 2: 150-174.

Ritland, K., and Clegg, M.T. 1987. Evolutionary analysis of plant DNA sequences. Am. Nat. 130: 74-100.

Shinozaki, K., and Sugiura, M. 1982. The nucleotide sequence of the tobacco chloroplast gene for the large subunit of ribulose 1,5-bisphosphate carboxylase-oxygenase. Gene, 20: $91-102$.

Sourdis, J., and Nei, M. 1988. Relative efficiencies of the maximum parsimony and distance-matrix methods in 
obtaining the correct phylogenic tree. Mol. Biol. Evol. 5: 298-311.

Wilson, M.A., Gaut, B., and Clegg, M.T. 1990. Chloroplast DNA evolves slowly in the palm family (Arecaceae). Mol. Biol. Evol. 7: 303-314.

Wolfe, K.H., Gouy, M., Yang, Y.-W., Sharp, P.M., Li, W.-H. 1989. Date of the monocot-dicot divergence from chloroplast DNA sequence data. Proc. Natl. Acad. Sci. U.S.A. 86: 6201-6205.

Wu, C.-I., and Li, W.-H. 1985. Evidence for higher rates of nucleotide substitution in rodents than in man. Proc. Natl. Acad. Sci. U.S.A. 82: 1741-1745.
Zimmerman, L.J., and Fuscoe, J.C. 1991. Direct DNA sequencing of PCR products. Environ. Mol. Mutagen. 18: 274-276.

Zuckerkandl, E., and Pauling, L. 1965. Evolutionary divergence and convergence in proteins. In Evolving genes and proteins. Edited by V. Bryson and H.G. Vogel. Academic Press, New York. pp. 97-166.

Zurawski, G., Clegg, M.T., and Brown, A.H.D. 1984. The nature of nucleotide sequence divergence between barley and maize chloroplast DNA. Genetics, 106: 735-749. 